УДК 004.42

\title{
ДОСЛІДЖЕННЯ ПРОГРАМНОГО ЗАБЕЗПЕЧЕННЯ ДЛЯ ВИЯВЛЕННЯ ТА ВИПРАВЛЕННЯ ДЕФЕКТІВ ЗD ДРУКУ
}

\section{Л.П. Голубєв, кандидат технічних наук, доцент \\ Національний технічний університет Украйни «КПI ім. І. Сікорського» \\ І.Л. Ківа, кандидат технічних наук, доцент \\ Київський національний університет технологій та дизайну \\ В.В. Романенко, магістрант \\ Київський наиіональний університет технологій та дизайну}

Ключові слова: 3D друк, комп'ютерний зір, 3D принтер, траєкторія позиціонування, КМОП-матриця, екструдер.

Технологія 3D друку в даний час переживає справжній бум. Вона широко використовується як в потоковому промисловому виробництві, так i в дрібносерійному виробництві на середніх і малих підприємствах. Однак в процесі 3D друку досить часто виникає відхилення параметрів готового зразка від розробленої 3D моделі. Тому завдання виявлення i усунення дефектів 3D друку в даний час стоїть особливо гостро [1].

Запропоновано новий метод виявлення і виправлення дефектів 3Dдруку, заснований на застосуванні технологій комп'ютерного зору. Працює це досить просто: програма починає 3 перевірки висоти в бічній проекції i аналізує віртуальний вид зверху на відповідність форм друкованих структур заданим контурам 3 використанням мультишаблонного порівняння та ітераційних алгоритмів, просторово-частотних фільтрів, гаусових моделей для розподілу і сегментування структурних аномалій за допомогою алгоритму агломератної ієрархічної кластеризації [2]. Це для того щоб візуально відстежувати форму друкованих шарів та порівнює їх з тим, що повинно бути згідно командам в G-коді, а потім вирішує, що робити далі.
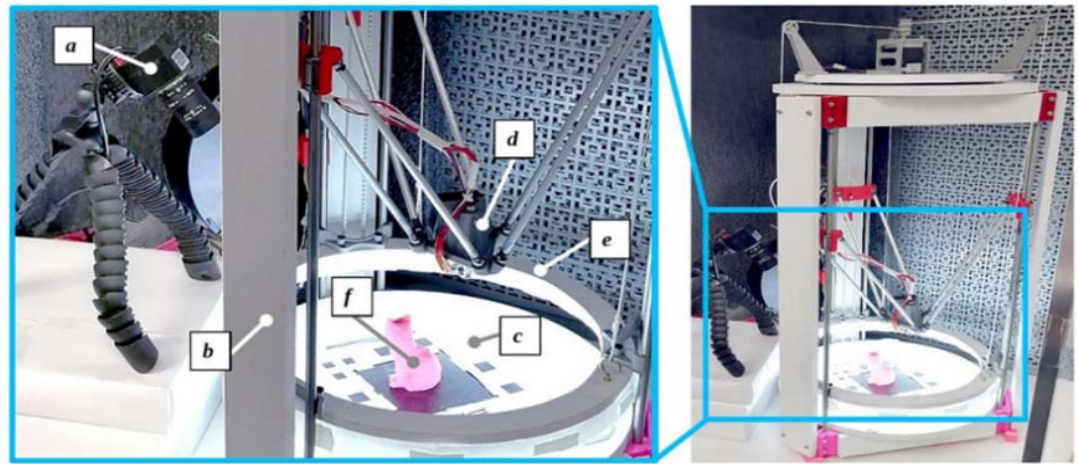

Рисунок 1 -Платформа візуального серво-управління: робоча зона (зліва), 3Dпринтер (справа): а- камера; b- рама принтера; с- пластина візуального маркера на нагрівній платформі; d-екструдер; е- рухома рамка з підсвіткою; f- об'єкт, який друкується

Для реалізації запропонованого метода було використане таке апаратне забезпечення: встановлена під кутом до робочої області камера на основі КМОП-матриці, в даному випадку SonyEXMOR IMX322, маркерна 
розмітка на нагрівній платформі, щоб програма могла визначати іiі положення в просторі відносно самої камери, ще необхідна світлодіодна підсвітка, яка синхронізована по висоті 3 нанесеними шарами для забезпечення стабільних результатів роботи машинного зору. У дослідах використовувався 3D принтер з кінематикою дельта-робот.

Програмне забезпечення, розроблене в середовищі Python. Воно аналізує G-код, розділяючи його на шари i сегментує по траєкторії екструдера на такі категорії: спідниця, заповнення, зовнішні і внутрішні стінки, опори для підтримки.

Траєкторії позиціонування залежать від алгоритму, який використовується для нарізки STL-файлів, i не завжди в точності збігаються 3 контурами в початкових цифрових моделях, бо в кожного слайсера свій алгоритм. Тому надійніше орієнтуватися на координати

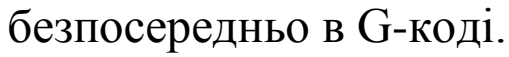

Потім, вже в процесі 3D друку, програма порівнює фізичні шари 3 віртуальними по контуру та висоті, враховуючи нахил камери і генеруючи виправлені зображення у верхній i бічній проекції. Можна було б використовувати дві камери, але, використання монокулярної системи знижує обчислювальне навантаження, не кажучи вже про економію на обладнанні.

Температура друку, траєкторії, швидкість позиціонування, швидкість подачі матеріалу, товщина шарів i iнші параметри зберігаються для кожного шару. Програмне забезпечення розраховане не тільки на аналіз, але і на повноцінний контроль робочих процесів.

Алгоритми роботи системи при виявленні різних проблем виконують відповідну дію. Наприклад, в разі коли модель відпала від поверхні, або через брак нитки, 3D принтер припиняє друк та інформує оператора. В разі закупореного сопла принтер призупиняє роботу, переміщує друкуючу голівку від моделі. Підвищує температуру хотенда, продавлює пластик та повторює 3D друк пропущеного фрагмента, в разі відхилень від вихідного контуру вносяться координатні поправки в G-код. Коли відбувається недоекструзія, то підвищується температура хотенда та збільшується темп подачі матеріалу, а в разі загинання перших шарів, підвищується температура нагріву столика.

Таким чином, розроблена технологія контролю трьох- вимірного друку за допомогою комп'ютерного зору може стати доволі корисною для виявлення та виправлення дефектів 3D друку й автоматизації виробництва, а також допоможе покращити якість друку.

\section{Список використаних джерел}

1. Гнеденко Б.В. Математика и контроль качества продукции / Б. В. Гнеденко. - ЛКИ, 2012. - 64 с.

2. Келер А. Изучаем OpenCV 3 /Келер Адриан, Брэдски Гэри :пер. 3 англ./ Слинкин А. А. - ДМК Пресс, 2017. - 826 с. 